\title{
Mulasztás és engedetlenség: a csernobili atomkatasztrófa néhány tanulsága*
}

\section{OMISSION AND NON-COMPLIANCE: LESSONS FROM THE CHERNOBYL NUCLEAR DISASTER}

\author{
Tanács János ${ }^{1 \dagger}$, Danka István ${ }^{1,2}$ \\ ${ }^{1}$ Markerting és Üzleti Kommunikáció Tanszék, Gazdaságtudományi Kar, Neumann János Egyetem, \\ Magyarország \\ 2 Filozófia és Tudománytörténet Tanszék, Gazdaságtudományi Kar, Budapesti Műszaki és \\ Gazdaságtudományi Egyetem \\ https://doi.org/10.47833/2020.3.ECO.002
}

\section{Kulcsszavak: \\ csernobili atomkatasztrófa \\ INSAG-7 \\ mulasztás \\ reaktivitási tartalék \\ szabálykövetés}

\section{Keywords:}

Chernobyl nuclear disaster

INSAG-7

omission

operative reactivity margin

rule-following

\section{Cikktörténet:}

Beérkezett 2020. október 28.

Átdolgozva 2020. október 30.

Elfogadva 2020. október 31.

\begin{abstract}
Összefoglalás
A csernobili atomkatasztrófa kiváltó okai - az első jelentésekben foglaltakkal ellentétben - nem az operátorok által elkövetett többrendbeli szabályszegésben keresendők, hanem tervezési és elöírásbeli hiányosságok eredményeként jött létre. Ugyanakkor a Nemzetközi Atomenergia Ügynökség jelentése egyetlen területen állapitott meg a baleset előidézésében szerepet játszó tényleges szabályszegést: a reaktivitási tartalékkal kapcsolatos előírás megsértése a baleset súlyosságát fokozó hozzájáruló ok szerepét játszotta.

E tényleges szabályszegés kapcsán arra szeretnénk felhívni a figyelmet, hogy ez nem értelmezhető a szabályvezérelt viselkedés legalapvetöbb, azt engedelmességi kérdésnek tekintő fogalmi keretei között.

A technológiai elöírások követésére való hajlandóságot befolyásoló tényezők feltárása - ismeretelméleti és tudásalkalmazási relevanciája mellett - hozzájárulhat a veszélyes technológiák biztonságosabb müködtetéséhez.

\section{Abstract}

Contrary to claims of the first report, the initiating causes of the Chernobyl nuclear disaster are not to be found in multiple rule violence of the operators but deficiencies in design and regulation. The International Atomic Energy Agency reported only one rule violence that had really played a role in the initiation of the accident: breaking a rule related to the Operating Reactivity Margin had been a contributory cause increasing the seriousness of the disaster. This factual rule violence cannot be explained by the most fundamental conceptual framework of Rule Governed Behavior that takes it as (com)pliance.
\end{abstract}

\footnotetext{
* Köszönettel tartozunk a cikk megírása kapcsán nyújtott segítségért és konzultációért Dr. Horváth Ákosnak, az MTA Energiatudományi Kutatóközpont főigazgatójának.

† Kapcsolattartó szerző. Tel.: +36 702573495

E-mail cím: tanacs.janos@gtk.uni-neumann.hu
} 


\begin{abstract}
While being relevant for epistemology and knowledge application, an exploration of factors influencing willingness of following technological regulations can also contribute to safer operation of dangerous technologies.
\end{abstract}

\title{
1. Bevezetés
}

A Nemzetközi Atomenergia Ügynökség (NAÜ, azaz International Atomic Energy Agency, IAEA) Nemzetközi Nukleáris Tanácsadó Csoportjának (International Nuclear Safety Advisory Group, INSAG) a csernobili atomerőmü-baleset körülményeit feltáró INSAG-7 jelentése számos ponton felülbírálta az 1986-os INSAG-1 jelentést. A legjelentősebb módosulások közé tartozik a baleset előidézésében a kiváltó ok szerepét játszó tervezési hiba felszínre kerülése és az operátorok által elkövetett szabályszegések megítélésének megváltozása. Az INSAG-7 jelentés a közvetlen előidéző okok vonatkozásában lényegében levette az operátok válláról az üzemeltetési előírások megszegéséből adódó felelősség terhét, és döntően a tervezési hibára helyezte át [1](p.24). Az INSAG-7 szerint ugyanis az első jelentésben megállapított szabályszegések a következőkben tárgyalt egyetlen kivétellel - a vonatkozó elöírások hiányában vagy nem voltak ténylegesen szabálysértések [1](p.24), vagy pedig nem volt szerepük és jelentőségük a baleset előidézésében, ideértve azt is, hogy i) betartásuk nem akadályozta volna meg a baleset bekövetkeztét, illetve ii) nem csökkentette volna súlyosságát.

A második jelentés a reaktor konstrukciós hibájaként azonosította, hogy bizonyos körülmények között a hűtőfolyadékban található gőzbuborékok térfogataránya növekedni kezd: ilyenkor az üregegyüttható pozitívá válik, azaz a reaktivitást fokozza. Ilyen körülménynek számít például a balesetet megelőző időszak során fennállt, a 3200 MW névleges hőteljesítményhez képest alacsony teljesítményen, 200 MW hőteljesítményen történő üzemelés is, amikor reaktivitást befolyásoló tényezők között az üregtényező válik dominánssá. Ekkor a gőzbuborékok megnövekedett térfogataránya következtében a reaktor nagyon érzékennyé válik a teljesítményingadozásra: egységnyi teljesítménynövekedés a reaktivitás növekedéséhez, azaz a láncreakció fokozódásához vezet [1](p.8), [2](p.90-90).

A szabályozó és biztonságvédelmi rudak kialakítása kapcsán is azonosítottak egy tervezési hibát: a teljesen kihúzott rudak betolásakor fellépő kezdeti pozitív reaktivitás-bevitelt, amely további többletként adódott hozzá az alacsony teljesítményen domináns gőzbuborékok okozta reaktivitás-növekedéshez. A túlzott mennyiségben és mértékben kihúzott szabályozó és biztonságvédelmi rudak betolásakor jelentkező hatást úgy értékelték, hogy ez valószínüleg meghatározó hozzájáruló tényezőként játszott szerepet a baleset előidézésében, illetve súlyosbításában [1](p.23). Az INSAG-7 végeredményben a túl nagy mennyiségben és mértékben kihúzott szabályozó és biztonságvédelmi rudakkal kapcsolatos elöírások megszegését, azaz a túl alacsony reaktivitási tartalékon (Operating Reactivity Margin, a továbbiakban ORM) történő müködtetésre vonatkozó szabályok tényleges megszegését állapította meg [1](p.18). Az ORM-mel kapcsolatos elöírás megszegésének státusza is változott annyiban, hogy a második jelentés szerint már nem kiváltó okként, hanem csupán jelentős hozzájáruló tényezőként játszott szerepet a balesetben. Összességében a reaktivitási tartalékra vonatkozó elöírás megszegése az eredetileg megállapított hat elöírásszegésből az egyetlen maradt, amelyet a NAÜ az operátorok által ténylegesen elkövetett szabályszegésként azonosított, és amely jelentősen hozzájáruló okként valóban szerepet játszott a balesetben (1. táblázat).

Az INSAG-7 jelentés technikafilozófiai jelentőségét az adja, hogy alkalmas a technológiai és üzemeltetési elöírások betartásával, betarthatóságával kapcsolatos tanulságok levonására, hiszen a NAÜ beszámolója az elöírásszegés súlyánál fogva önkéntelenül is több figyelmet szentel neki, megragadhatóbb és elemezhetőbb alapanyagot biztosítva további, mélyebb belátásokhoz. Mindezt figyelembe véve a jelen tanulmányban azt fogjuk vizsgálni, hogyan értelmezi - lényegében hallgatólagosan - a szabálykövetési helyzetet a NAÜ jelentése, és ez alapján milyen tanulságok szürhetők le a szabálykövetési, elöírásbetartási szándékra vonatkozóan. A tanulmányban azt szeretnénk megmutatni, hogy az INSAG-jelentés - önkéntelenül és hallgatólagosan - kilép abból a naiv keretböl, amely szerint a szabálykövetés pusztán fegyelmezettségi, engedelmességi kérdés lenne, és amelyet az elöírások ismeretében minden további nélkül elvárhatunk. Az INSAG-7 jelentésnek a reaktivitási tartalékkal kapcsolatos elöírások megszegésére vonatkozó megjegyzéseiből kibomlik, hogy vannak olyan további tényezők, amelyek a technológiai előirások követésére, a szabálybetartásra való hajlandóságot érdemben befolyásolják. Ezen tényezők felszínre hozása, megragadása megnyitja az utat annak az ismeretelméleti és tudásalkalmazási helyzetnek a mélyebb 
megértéséhez, amellyel a technológiai és üzemeltetési előírások célszemélyei az értelmezői és alkalmazói oldalon szembe találják magukat. Mindez végeredményben hozzájárulhat a veszélyes technológiák

\begin{tabular}{|c|c|}
\hline $\begin{array}{l}\text { Az INSAG-1-ben megállapított } \\
\text { szabályszegés }\end{array}$ & $\begin{array}{c}\text { Az INSAG-7 értékelése a korábbi megállapításra } \\
\text { vonatkozóan }\end{array}$ \\
\hline $\begin{array}{l}\text { A reaktor } 700 \mathrm{MW} \text { (th) teljesítményszintnél } \\
\text { alacsonyabb teljesítményen történő } \\
\text { folyamatos működésére vonatkozó tilalom } \\
\text { megszegése. }\end{array}$ & $\begin{array}{l}\text { Elvileg kellett volna lennie ilyen tiltásnak, de a baleset idején } \\
\text { nem volt érvényben ezzel kapcsolatos előírás. } \\
\text { Elöírás hiányában nem szabályszegés. }\end{array}$ \\
\hline $\begin{array}{l}\text { A nyolc fő hütőszivattyú maximális } \\
\text { térfogatáram mellett történő müködtetése } \\
\text { oly módon, hogy a térfogatáram értékek } \\
\text { több esetben meghaladták az előírt } \\
\text { értékeket. }\end{array}$ & $\begin{array}{l}\text { A nyolc szivattyú egyszerre történő működését egyetlen } \\
\text { dokumentum sem tiltotta, ideértve a turbógenerátor teszt } \\
\text { eljárási rendjét is. } \\
\text { Ugyanakkor a térfogatáram értékek túllépték a } \\
\text { megengedettet, és megsértették a teszt ezzel kapcsolatos } \\
\text { elöírását. }\end{array}$ \\
\hline $\begin{array}{l}\text { Az erőmü túl alacsony ORM értéken } \\
\text { történő müködtetése az előírások } \\
\text { megszegése volt. }\end{array}$ & $\begin{array}{l}\text { Az INSAG-7 is megismétli, hogy a túl alacsony ORM } \\
\text { értéken történő müködtetés az elöírások megszegése volt. } \\
\text { Az elöírás tényleges megszegése azonban a korábban } \\
\text { megállapítottaktól eltérő okokból volt fontos: ez } \\
\text { eredményezte a megnövekedett üregtényezőt. A túlzott } \\
\text { mértékü kihúzás nemcsak hatástalanította a védelmi } \\
\text { rendszert, hanem pusztítóvá is tette. }\end{array}$ \\
\hline $\begin{array}{l}\text { A reaktorvédelem egyik összetevőjének } \\
\text { kiiktatása No1.: zóna vészhűtő rendszer } \\
\text { (ECCS) kikapcsolása. }\end{array}$ & $\begin{array}{l}\text { A zóna vészhütő rendszer (ECCS) normál üzemi } \\
\text { körülmények között történő kikapcsolását valójában nem } \\
\text { tiltotta elő́rás. } \\
\text { Előírás hiányában tehát nem szabályszegés, és a rendszer } \\
\text { kiiktatása nem befolyásolta a balesetet. }\end{array}$ \\
\hline $\begin{array}{l}\text { A reaktorvédelem egyik összetevőjének } \\
\text { kiiktatása No2.: a „gőzleválasztó dob } \\
\text { szintje alacsony” vészleállító jel bénítása.. }\end{array}$ & $\begin{array}{l}\text { A jel bénítása elvileg nem tiltott, megengedhető,. } \\
\text { Ezen kívül a balesetet sem befolyásolta, tovább létezett } \\
\text { még más védelmi vonal. }\end{array}$ \\
\hline $\begin{array}{l}\text { A reaktorvédelem egyik összetevőjének } \\
\text { kiiktatása No3.: } \\
\text { a „turbinakiesés” vészleállitás jel letiltása. }\end{array}$ & $\begin{array}{l}\text { A „turbinakiesés” jel bénítása megengedhető volt, és } \\
\text { alacsony teljesítményszinteknél, mint amilyen például a } \\
\text { turbógenerátor teszt volt, valóban szükség is volt rá. }\end{array}$ \\
\hline
\end{tabular}

\section{Táblázat. Az INSAG-1 jelentésben megállapitott elöírásszegések átértékelése az INSAG-7 jelentésben ([1](p.18); [2](p.94] alapján)}

\section{A minimális reaktivitási tartalékra vonatkozó előírás megszegése és jelentősége}

A Csernobili Atomerőmű üzemviteli szabályzata rögzítette, hogy a reaktor 3-as és 4-es blokkjának bizonyos teljesítményeihez milyen reaktivitási tartalékok, illetve bizonyos ORM értékekhez milyen cselekvések tartoznak. A reaktivitási tartalék az a többlet reaktivitás, amely akkor keletkezne, ha a biztonságvédelmi és szabályozó rudak adott pillanatbeli konfigurációjához képest az összeset teljesen kihúznák a reaktormagból. Az ily módon előálló elvi értéket az egy standard rúdra vonatkoztatott rudak számában adják meg. Az a reaktivitási tartalék az egységnyi, amelyet egy standard rúd a teljesen betolt állapotból a teljesen kihúzott állapotba jutás révén idéz elő a reaktivitás növekedésében [1](p.6).

A szabályzat 9. szakasza szerint „a névleges teljesítményen, állandósult üzemállapotban müködő erőmü esetében az ORM nem lehet kisebb, mint 26-30 rúd. Amennyiben az ORM értéke kisebbé válik, mint 26, a reaktor további müködését az Erömü Főmérnökének kell engedélyeznie. Ha pedig az ORM értéke eléri vagy kisebbé válik, mint 15 rúd, a reaktort haladéktalanul le kell állítani” [1](p.79, p.106).

A második jelentés a szabályozó és biztonságvédelmi rudak kialakítása kapcsán is tervezési hibát állapított meg (más konstrukciós problémák mellett). A rudak tervezési hibájához kapcsolódó utólagos elemzések és szimulációk pedig rámutattak arra, hogy az üzemviteli szabályzatban rögzített, az azonnali leállítást megkövetelő abszolút minimum ORM érték $\left(O R M_{\min }=15\right)$ betartása valóban kritikusnak tekinthető a védelmi 
rendszer hatékonysága és hibamentes müködése szempontjából. Ennek megértéséhez első lépésben érdemes megértenünk a rudak szerkezetét és a kapcsolódó tervezési hibát.

A szabályozó és védelmi rudak anyaga a bór-karbid ötvözet, amely abszorbens, azaz fékezi a láncreakciót. A reaktormagba betolt rudak abszorbens anyagból készült részének szerepe, hogy csökkentsék a reaktivitást, míg az abszorbens anyagú rúdszakaszok kihúzása növeli (1. ábra). Ugyanakkor a rudakhoz egy vízkiszorító grafitcsúcs csatlakozott, amelynek szerepe az volt, hogy a magból kihúzott neutronelnyelő egység helyét ne a láncreakció szempontjából szintén elnyelő, a folyamatot fékező víz foglalja el, hanem a láncreakciót fenntartó, azaz moderátorként funkcionáló grafit. A teljesen kihúzott helyzetű rudak esetében az abszorbens szakasz teljesen a magon kívül foglal helyet, miközben az ehhez csatlakozó grafitcsúcs a magban helyezkedik el. A teljesen kihúzott rudak betolása során, amikor a bór-karbid szakasz elkezd belépni a magba, elkezdi csökkenteni a reaktivitást a belépési pontnál, azaz a reaktor felső részén. Ezzel együtt a vízkiszorító grafitcsúcs is lejjebb kerül a magban, aminek következménye kettős. A grafit által elfoglalt térrészbe beáramló víz szintén csökkenti a reaktivitást, azonban a mag azon alsóbb részén, ahonnan a rúd grafitvége kiszorítja a vizet, éppen hogy növekszik a reaktivitás a grafit neutronmoderáló hatásának eredményeként. Így a mag felsőbb részein összességében valóban csökken a reaktivitás, azonban a rúd betolásának első időszakában a mag alsó részén növekszik, egészen addig, amíg a rúd vízkiszorító grafitcsúcsa el nem éri a reaktormag alját (2. ábra).

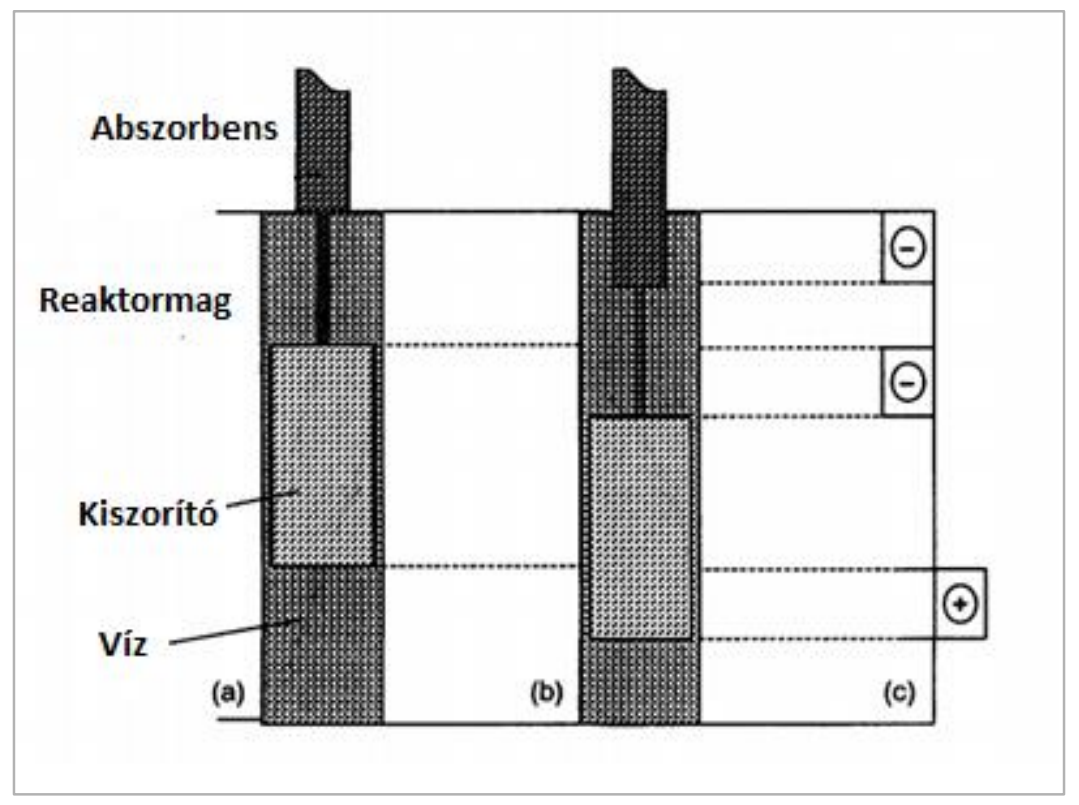

1. ábra. A reaktor szabályozó és biztonságvédelmi rúdjainak sematikus szerkezete és az általuk bevitt reaktivitás a rúd betolásakor. (a) Teljesen kihúzott kézi szabályzó rúd: a neutronabszorbens szakasz teljesen a reaktormagon kívül (b) Részben betolt szabályzórúd (c) Az elméleti reaktivitás-bevitel a rúd betolása során: a negatív szakaszok csökkentik a reaktivitást, a pozitív szakasz a reaktormag alján növeli ([1](p.124, Fig. II-10.) alapján).

Adott pillanatban az erőmủ adott állapotában a teljesen betolt, a részben betolt és a teljesen kihúzott rudak adott konfigurációja (más tényezők mellett) megszabja, hogy a rudak beljebb tolása vagy kijjebb húzása hogyan változtatja a reaktivitási tartalékot. A követhetőség miatt a legegyszerübb helyzetekre koncentrálva: egy teljesen kihúzott rúd (vagy rudak egy csoportjának) betolásakor a már részben vagy teljesen betolt rudak neutronelnyelő képessége kompenzálja a teljesen kihúzott állapotból betolás alatt álló rudak által bevitt és a mag alsó részén pozitív reaktivitást. Minél több a teljesen kihúzott rúd, annál több a kezdeti negatív reaktivitásbevitel a mag felső részén, viszont sajnos annál több a kezdeti pozitív reaktivitás-bevitel a reaktormag alsó részében és annál kevesebb a részben vagy teljesen betolt rudak neutronelnyelő képessége. Mindez egy bonyolult egyensúlyt ad ki, amely abban is megmutatkozik, hogyan változik a szabályozó és biztonságvédelmi 
rudak reaktivitáscsökkentési hatékonysága a reaktivitási tartalék, azaz az ORM-szám függvényében. Ez a hatékonyság egyrészt a reaktivitáscsökkentés gyorsaságát jelenti, másrészt azt, hogy a rudak egyáltalán be tudják-e tölteni a reaktivitáscsökkentési, azaz lényegében védelmi szerepüket.

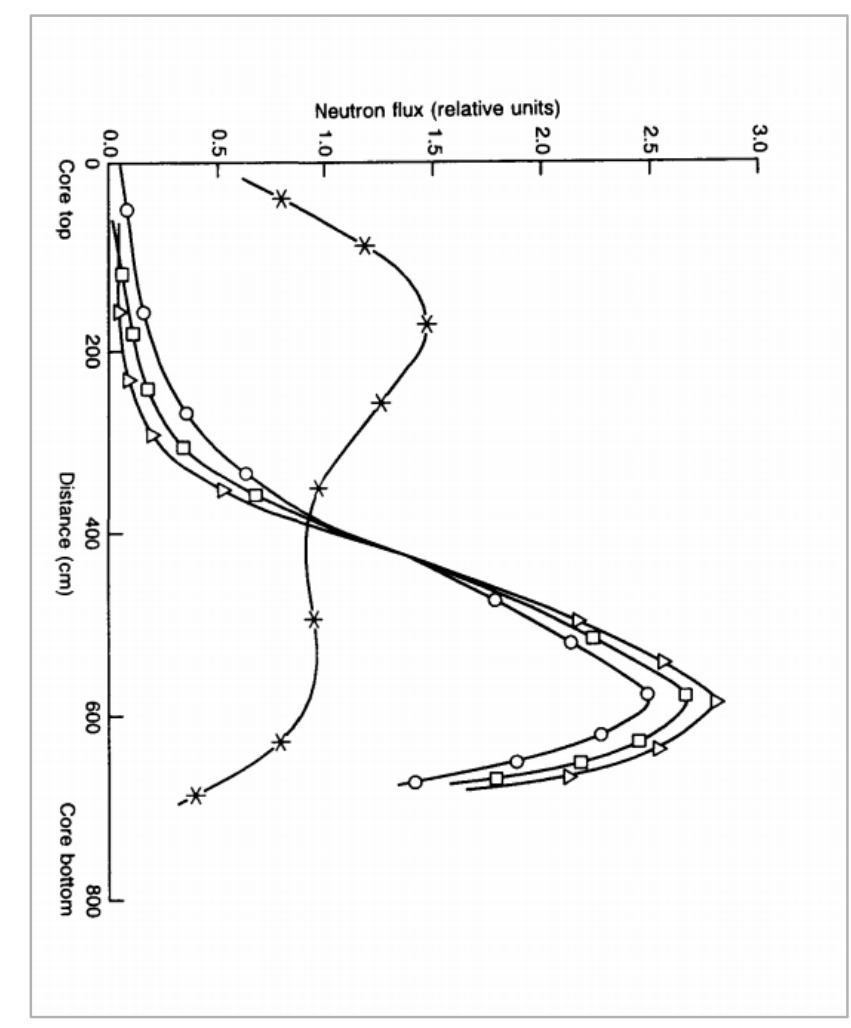

2. ábra. A neutronmező tengely irányú eloszlásának torzulása a szabályozó és védelmi rúd betolásakor a csernobili baleset bekövetkezésének pillanataiban. Egyértelmüen látszik a neutron fluxus maximumának eltolódása a reaktormag alsó részének irányába. ([1](p.122,

Fig. II-9.) alapján). (Az eredeti ábrát elforgattuk, hogy a jelenség könnyebben vonatkoztatható legyen az 1. ábrára.) Jelöléskulcs: az EPS-5 vészleállító gomb megnyomását követöen eltelt idö: *: $0 \mathrm{~s} ; 0: 4 \mathrm{~s} ; \square: 6 \mathrm{~s} ; \Delta: 7 \mathrm{~s}$.

A 3. ábra a vészhelyzeti védelmi rendszer hatékonyságának alakulását mutatja különböző ORM értékekre a balesetet követő szimuláció eredményeként. Az ábra 3. és 4. számú jelleggörbéje már a baleset után áttervezett végü rudakra vonatkozik, és ezért a baleset körülményeire nem vonatkoztatható. Az áttervezés két célja ugyanis a rudak konstrukciós hibájának kiküszöbölése, és a teljes rúd bejuttatási idejének 18 másodpercről 12 másodpercre csökkentése volt [1](p.4, p.27, p.145).

Az ábrán jól látható, hogy a névlegesen teljesítményen, állandósult állapotban müködő reaktorra megszabott $O R M_{\min }=30$ érték esetén a reaktivitáscsökkenés az áttervezett rudak esetén meglehetősen gyors, a védelmi rendszer hatékony (3-as jelleggörbe). Ugyanez igaz az ún. gyorsmüködésű vészhelyzeti védelmi rendszerbe tartozó rudak esetén is: kevesebb, mint 2 másodperc alatt radikális reaktivitáscsökkenést eredményeznek a teljes 12 sec-es betolási idő első pillanataiban (4-es jelleggörbe).

Az eredeti rúdvégkialakításra vonatkozó két jelleggörbéből azt tudjuk leszűrni, hogy az előírás által megszabott abszolút minimum reaktivitástartalék érték $\left(O R M_{\min }=15\right)$ esetén (2-es jelleggörbe) a reaktivitáscsökkenés sokkal lassabb, mint a baleset után áttervezett rudak esetében lenne, viszont itt még képes a rudazat betölteni a védelmi szerepet: képes a reaktivitás csökkentésére. A baleset idején fennáló ORM=7 érték esetén (1-es jelleggörbe) azonban nem csupán az a baj, hogy rendszer lassú, hanem a kezdeti csökkenés után kb. 2 másodperccel a reaktivitás jelentős növekedésbe megy át. Ilyen körülmények között a vészhelyzeti védelmi 
rendszer nem csupán nem látja el a feladatát, hanem szándékolt szerepével ellentétesen fokozni kezdi a láncreakció intenzitását.

Összességében a 3. ábra világosan mutatja, hogy az ORM=15 érték környékén a védelmi rendszer kevésbé hatékonyan, de még képes ellátni szerepét, és $\mathrm{ORM}<15$ érték esetén e védelmi képesség fokozatosan elveszik, majd létrejön a láncreakció fokozását és ezzel a reaktor megszaladását katalizáló hatás. Mindez érthetővé teszi, hogy az ORM $M_{\min =15}$ értéket rögzítő előírás betartása a vészhelyzeti védelmi rendszer hatékonysága szempontjából kulcsfontosságú: az előírás megszegése első lépésben a vészhelyzeti védelmi rendszer „hatástalanítását” eredményezte, második lépésben pedig a védelmi rendszer maga is hozzájárult a reaktor megszaladásához: a baleset létrejöttéhez és súlyosbodásához.

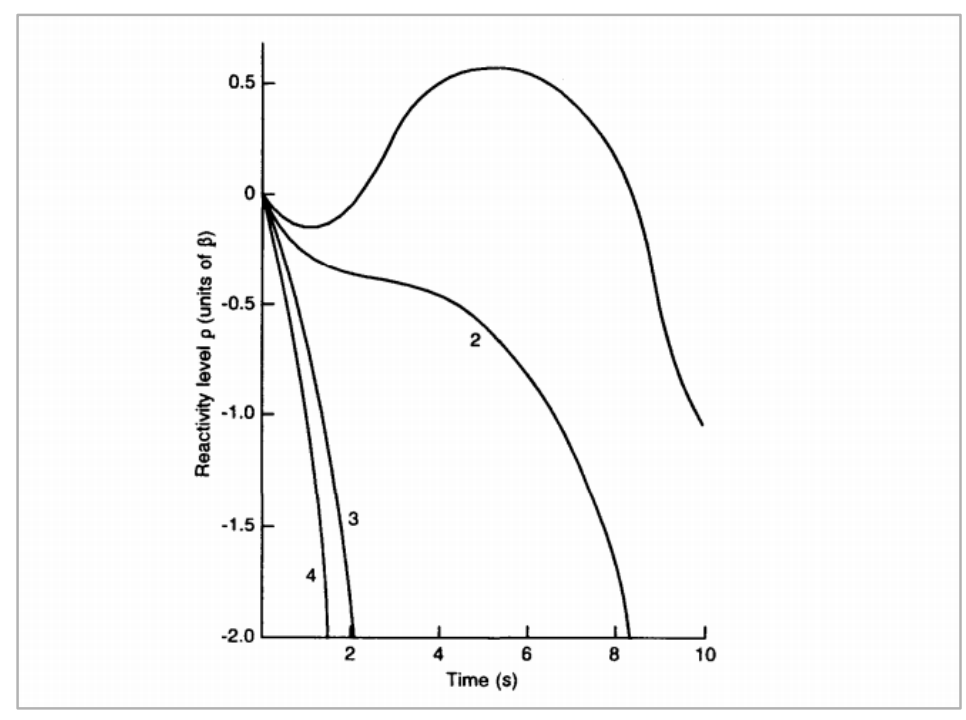

3. ábra. A reaktor vészhelyzeti védelmi rendszerének hatékonysága különböző ORM értékekre szimulálva. (1) A baleset bekövetkezésének idején, ORM=7 db. kézi szabályzó rúd érték fennállásakor (2) Az üzemviteli szabályzatban meghatározott ORM=15 alsó korlátérték esetén (3) ORM=30 rúdérték esetén (4) Gyorsmüködésü vészhelyzeti védelmi rendszer esetén ([1](p.131, Fig. II-15.) alapján).

Miközben a reaktivitási tartalék konkrét értéke döntő volt az előírás betartása és a vészhelyzeti védelmi rendszer tervezési szerepe szempontjából, aközben az értékhez csak nagyon körülményesen lehetett hozzáférni [1](p.172). Ennek oka a következő. Ahogy fentebb láttuk, az erőmü müködése során a reaktormagba teljesen betolt, részben kihúzott és teljesen kihúzott rudak különböző kombinációi álltak elő adott müködési állapotban. Az ORM értéke azonban nem állt az operátorok rendelkezésére bármely pillanatban, hanem egy adatvételi és kalkulációs eljárás révén kellett meghatározni. Egy időigényes eljárás adta meg, hogy a reaktormagba teljesen betolt, részben kihúzott és teljesen kihúzott rudak adott pillanatnyi térbeli kombinációja alapján az ORM értéke az egyenértékes rúdra átszámolva mennyinek tekintendő. Ezt a kalkulációt az üzemeltető két módon is elvégezhette, ám mindkettő időigényes és körülményes volt. Az egyik módszer szerint a mérőmüszer rúdjainak középső helyzetbe engedése után, a mérőskála nemlinearitásának korrekcióját elvégezve és az eredmények összegzését követően állt elő az egyenértékes rúdra vonatkoztatott ORM érték. A másik módszer szerint az erőmű számítógépes rendszerét kellett utasítani a mérés és számítás elvégzésére. Bármely esetben az ORM értékének meghatározása 10-15 perces időt vett igénybe. Ehhez társult, hogy az ORM érték meghatározására szolgáló berendezés az operátorok által használt kezelőpaneltől 50 méter távolságban helyezkedett el [1](p.6, p.72). 


\section{A minimális reaktivitási tartalékra vonatkozó előírás megszegése a balesethez vezető események folyamatában}

Az 1986. április 26-án hajnali 1:24-kor a csernobili atomerőmű 4. blokkjában bekövetkezett balesethez vezető események az április 25-én 1:06 perckor útjára indított teszttel vették kezdetüket. A kísérlet első lépéseként a reaktor teljesítményét fokozatosan a névleges teljesítmény 50\%-ára csökkentették, amely hajnali 3:47-kor 1600 MW teljesítményen stabilizálódott. Reggel 6 és 9 óra között folytatólagosan kisebb volt a reaktivitás, mint az elöírt korlát, amelyet 7:10-kor rögzítettek is az üzemeltetési naplóban. Az üzemeltetési napló szerint ugyanis 7:10-kor a reaktivitási tartalék 13.2 egyenértékes kézi működtetésű szabályozó rúdnak felelt meg [1](p.53). Amikor Igor Kazacskov, a nappali müszak (8-16 óra között) vezetője reggel 8 órakor átvette a reaktort, az ORM továbbra is kisebb volt, mint az elöírt $O R M_{\min }=15$ [3](p.69). Ahogy fentebb láttuk, az üzemviteli szabályzat előirása szerint $\mathrm{ORM}<15$ esetén az atomerőmüvet haladéktalanul le kellett volna állítani, ezt tudták is, és mégsem tették meg [3](p.69).

A tesztprogram következő lépéseként 14:00-kor lekapcsolták az üzemzavari védelmi hütörendszert [1](p.53), [2](p.83), azonban a teszt folytatását a kijevi villamosenergia-hálózati teherelosztó-központ kérésére felfüggesztették. Az eredeti munkaprogram szerint a turbógenerátor-tesztnek és az erőmű leállításának a nappali müszak végéig, 16:00-ig be kellett volna fejeződnie. A reaktivitási tartalék 15:20-kor már 16.8-as értéket mutatott, tehát magasabb volt, mint a minimálisan elöírt ORM-érték, azonban az erőmü egészen 23:10ig, azaz tartósan a névleges teljesítmény 50\%-án müködött [1](p.53). A hálózati teherelosztó 23:10-kor engedélyt adott a kísérlet folytatására, az erömü teljesítményét tovább lehetett csökkenteni. Ekkor a reaktivitási tartalék 26 egyenértékes rúdnak felelt meg. A 23:10-kor kezdődött teljesítménycsökkentéssel párhuzamosan folyamatosan szabályozó rudakat húztak ki, és ezzel csökkentették a reaktivitási tartalékot is (4. ábra).

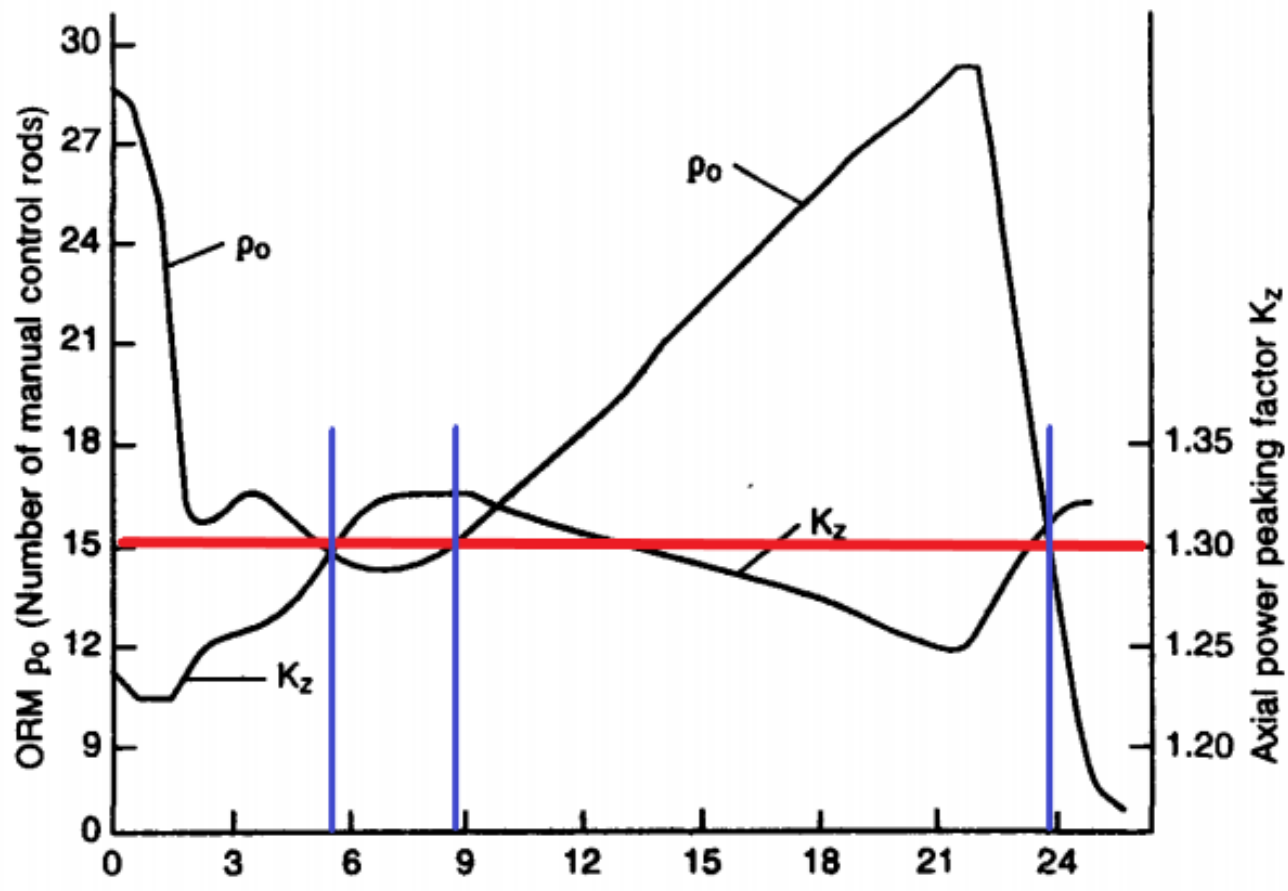

4. ábra. A reaktivitási tartalék $\left(\rho_{0}\right)$ változása a balesetet megelőző időszakban a turbógenerátor teszt kezdetének pillanatától ( $t=0: 1986$. április 25-én 1:06-kor). A piros vonal az $O R M_{\min }=15$ értékhez tartozik, a kék vonalak pedig az ehhez tartozó időpontok azonositását segítik. ([1](p.117,

Fig. II-4.) alapján szerkesztve, a piros és kék vonalak az eredetiben nem szerepelnek.)

A teszt közvetlen elökészületi fázisában, április 26-án 0:28-kor a reaktor szabályozó rendszerét lokálisról globálisra kapcsolták át, ekkor a teljesítmény váratlanul 720 MW-ról a 0-30 MW tartományba zuhant [1](p.112), 
[2](p.83). Az operátorok számára a teljesítmény ilyen mértékü beszakadása értelmezhetetlen jelenség volt, az előállt csökkenést kompenzálandóan pedig további szabályozórudakat húztak ki a zónából.

Innentől a számunkra fontos eseményeknek kétfajta leírása rekonstruálható. Az egyik szerint az üzemeltetési naplóban az április 25-én 23:10-es adatot követően nem került rögzítésre további, az ORM-re vonatkozó adat. Bár az 1:23:10-kor megkezdett kísérlet előtt 1:22:30-kor az ORM jelentősen kisebb volt, mint a minimálisan megengedett $15(\mathrm{ORM}=8)$ [1](p.54), ám ezt az adatot a kezelök nem ismerték, hanem csak a baleset utólagos számítógépes szimulációja révén kalkulált értékként állt elő az INSAG-jelentést készítők számára [1](p.54, p. 113). A másik történeti leírás azt sugallja, hogy a kezelők a teszt megkezdésekor (1:23:10) ismeretében voltak az 1:22:30-kor fennállt ORM értéknek, csak annak nem, hogy ez milyen veszélyt hordoz magában [1](p.78); [4](p.19).

Az eddigieket figyelembe véve azt mondhatjuk, hogy április 25-én és 26-án a baleset bekövetkeztéig az operátorok többször megsértették az Üzemviteli Szabályzat 9. szakaszának minimum 15 szabályozórúdnyi reaktivitási tartalékra vonatkozó előírását. A balesetet megelőző 24 órában a reaktivitási tartalék 25-én reggel 6 és 9 között (1. szabályszegési időszak), valamint 25-én éfféltöl a baleset bekövetkeztéig (2. szabályszegési időszak) többször és folytatólagosan az elöírt 15-ös minimális érték alatt volt [1](p.116-17) (4. ábra). E két szabályszegési időszak közül az első esetében két müszak (a 0-8 közötti reggeli, valamint a 8-16 közötti nappali műszakok) kezelőszemélyzete is tudatában volt a vonatkozó előírás megszegésének [3](p.69). A 2. szabályszegési időszak esetében a két különböző történeti leírás miatt két értelmezést különböztethetünk meg: az egyik szerint a 2. szabályszegési időszak során is tudtak a kezelők a minimális ORM-értékre vonatkozó elő́rás megszegéséről: ekkor összesen két szabályszegési időszak összesen négy műszakja érintett az ORM értékkel kapcsolatos szabályszegésben. A másik történeti bemutatás szerint a 2 . szabályszegési időszak éjszakás és reggeli müszakja nem volt tudatában, hogy megszegték az előírást [1](p.11), mert nem állt rendelkezésükre adat. Ugyanakkor a 2. szabályszegési időszak e két műszakja a 23:10-kor 50\%-os teljesítményszintről kezdeményezett további teljesítménycsökkentés érdekében folyamatosan szabályozó rudakat húzott ki az ORM-érték meghatározása nélkül. A teljesítményszint csökkentése érdekében folyamatosan történő rúdkihúzás következtében az elöírás ismeretének fényében tölük az a cselekvés várható el, hogy az ORMmin=15-ös alsó limit betartása érdekében szerezzék be az adatokat. Ebben az esetben tehát az adatok az elöírás betartásához szükségesek, ezért az adatok be nem szerzése a mulasztás. Ebböl adódik, hogy ezt mulasztásos szabályszegésnek tekinthetjük. Így e 2. történeti leírás fényében két műszak esetében tényleges szabályszegésről, és további kettő esetében mulasztásos szabályszegésröl beszélhetünk.

Összegezve: bár mutat némi bizonytalanságot, hogyan alakult pontosan a balesetet megelőző 24 órában az ORM értékének ismerete, azt biztosan lehet állítani, az erőmű működtetői tudtak a minimális ORM-re vonatkozó korlátozásról, valamint a korlát eléréséhez rendelt cselekvésről (az erőmű haladéktalan leállitása) [3](p.69). Az egyik történeti narratívát figyelembe véve a két szabályszegési időszak négy műszakja tényleges szabályszegést követett el, a másik történeti narratíva szerint az 1 . szabályszegési időszak két müszakja tényleges, míg a 2. szabályszegési időszak két műszakja mulasztásos szabályszegést követett el.

Az elöírás tudatos és szándékos megsértése tehát két műszak (0-8, valamint 8-16) során is megtörtént. Nem egyértelmủ, hogy az április 25-én 16-24 között dolgozó műszak végén, vagy a 26-án 0-8 közötti műszak során pontosan mikor állt fenn újra a korlátnál kisebb érték, illetve tudtak-e róla a kezelők. Az azonban rögzíthető, hogy vagy tudtak róla, hogy az ORM a korlát alatt van, vagy nem tartották fontosnak ismerni és elöállítani az értékét (a mérést és kalkulációt elvégezni), miközben ismerték a vonatkozó előirást és az ORM értékének önmagában ebből fakadó jelentőségét (azonnali leállítás szükségessége).

\section{A reaktivitási tartalékkal kapcsolatos szabályszegésre vonatkozó megjegyzések az INSAG-7-ben}

Az előzőekben láttuk, hogy vannak esetek, amikor a reaktorkezelök részéröl tényleges szabályszegéseket érhettünk tetten, amelyek tudatosak és szándékosak voltak, és vannak esetek, amikor mulasztásos szabályszegést valószínüsíthetünk. Láttuk ezeknek a balesetben játszott szerepét és jelentőségét. A 
következőkben azt vizsgáljuk, hogy mi következik abból, ahogy a NAÜ jelentése a szabály betarthatóságára, a szabálybetartási szándékra tekint.

A minimális reaktivitási tartalékkal, tágabban pedig a reaktivitási tartalékkal kapcsolatos előírások betartására vonatkozóan az INSAG-7 jelentés a következő észrevételeket teszi. Egyrészt, hogy az ORM nem szerepel az Üzemeltetési Szabályzatban a Fontos paraméterek listában [1](p.72). Másrészt, hogy az Üzemeltetési Szabályzat a reaktivitási tartalékot a nagyméretű és lazán kapcsolt reaktormag részek energiaeloszlásának kiegyensúlyozása szempontjából fontos tényezőként állította be [1](p.14). Azaz: a szabályzat a reaktivitási tartalékot csak, mint teljesítményszabályozási paramétert értelmezte, és egyáltalán nem pozícionálta a vészhelyzeti védelmi rendszer hatékonysága szempontjából fontos paraméterként [1](p.14, p.72). És végül a harmadik észrevétel az ORM-érték körülményes és lassú kalkulálhatóságához, az adatmegjelenítő berendezés operátorterembeli elhelyezéséhez [1](p.24), azaz általánosítva az adat hozzáférhetőségéhez kapcsolódik. Ugyanis ilyen nehézkes hozzáférés esetén „ésszerütlennek tűnik azt várni a kezelő személyzettöl, hogy ezt a paramétert [ORM] úgy tekintse, mint ami közvetlenül kontrollálható" [1](p.72).

A szabályok betartása, betarthatósága kapcsán rendszerint az elsöként elökerülö kérdés az ellentmondásosságra irányul. Valóban: ha két ellentmondó szabály létezik ugyanarra a helyzetre, akkor nem világos, hogy melyiket is kell követni, melyik szerint kell eljárni. Bár az INSAG-7 jelentés foglalkozik az ORMmel kapcsolatos elö́rások „ellentmondó természetével” [1](p.74, P.79-80), vagy általában a csernobili atomerőmü üzemeltetési elöírásainak „ellentmondó természetével” [1](p.86), érdemes rögzíteni, hogy az előző bekezdésben tárgyalt, az ORM-mel kapcsolatos előírás betarthatóságára vonatkozó észrevételek nem a szabályok ellentmondásos jellegére vonatkoznak. Például az ORM teljesítményszabályozási és vészhelyzeti védelmi szerepe nincs kizáró viszonyban egymással, csupán kiegészítik egymást. A probléma itt nem az, hogy a kezelők egyszerre nem tudták figyelembe venni e paraméterek jelentőségét, és betartani a kapcsoló elöírásokat, hanem az, hogy az egyik szerepről nem tudtak.

A szabályvezérelt viselkedés (Rule-Governed Behavior) koncepciója a szabálykövetés három típusát különbözteti meg: az engedelmesség alapút (com)pliance, az igazodáson alapulót (tracking), valamint a kiterjesztésen alapulót (augmenting) [5](p.145-147); [6](p. 685).

Az engedelmesség vagy fegyelmezettség alapú szabálykövetés a szabályvezérelt viselkedés azon esete, amikor a szabály és a viselkedés közötti megfelelést a szabály elöírója által kilátásba helyezett társas következmények (jutalmak és büntetések) tartják ellenőrzésük alatt. A szabályhoz illeszkedő viselkedés ennek az ellenőrző funkciónak köszönhetően jön létre. A cselekvő ilyenkor alárendeli magát a szabálynak. Hétköznapi elképzeléseink szerint lényegében ez hívjuk „vak szabálykövetésnek”. Ilyennek tekinthetjük például a szülői utasításokat, különösen a jutalmat vagy büntetést kilátásba helyező változatukban: „Edd meg a levest, és akkor kapsz fagyit!". Számos esetben a társas következmények látensek: bár az utasítás nem jeleníti meg a jutalmat vagy a büntetést, azonban a helyzetben egyértelműen megragadhatók. A csernobili atomerőmű működtetési körülményeihez jobban illő példa: „26 rúdnál kisebb ORM esetén a reaktor üzemeltetését az erőmű főmérnökének kell engedélyeznie.” Az erőmű működtetésének minden elöírása értelemszerủen feltételezi az engedelmesség alapú szabálykövetést, függetlenül attól, hogy a társas következmények, jutalmak és büntetések nincsenek a szabályokban explicitté téve.

Az igazodás esetében a szabály és a világ közötti összhang megteremtésének szándéka vezérli a cselekvést. Hétköznapi példával: „Fertőtlenítő kézmosás esetén folyékony szappant használjunk tisztítószerként, és a kézmosás ideje legalább 40-60 másodpercig tartson." Ha a szabálykövető nem pusztán egy kilátásba helyezett társas jutalmazási vagy büntetési következmény miatt követi az iménti elöírást, hanem mert kívánatosnak tekinti, hogy létrehozza az állapotot (fertőtlenített kéz), és ebből a szándékból végzi a cselekvést, akkor igazodásról beszélünk. A müszaki környezethez illeszkedő példa erre egy ilyen megfogalmazású szabály lehetne: „Ha az ORM értéke 15 rúdra csökken, a reaktort azonnal le kell állítani, hogy elkerülhető legyen a xenon-mérgezés következében előálló instabil állapot kialakulása."

És végül a kiterjesztésen alapuló szabályvezérelt viselkedés esetében a szabály megváltoztatja (kiterjeszti) az események szabályban specifikált következményének megerősitő értékét (jutalmazás vagy büntetés), és ezek a módosított következmények tartják ellenőrzésük alatt a cselekvést. Példa lehet erre, amikor azt mondja az anya: „Ha nem csak egészséges, hanem nagy és erős akarsz lenni kisfiam, akkor sok zöldséget és gyümölcsöt kell enned!" Ebben az esetben a sok zöldség és gyümölcs evése rendelkezik egy többlet, jelen 
esetben jutalmazó funkcióval, ami az egészségen túlmutató következményekkel kecsegtet. A csernobili atomerömű elöírásaira hangszerelt példa pedig a következő lehetne: „Ha az ORM értéke 15 rúdra csökken, a reaktort azonnal le kell állítani. A 15-nél kisebb ORM értéken müködtetett reaktorban elóálló xenon-mérgezés instabil állapot kialakulásához vezet, amely veszélyes üzemállapotot eredményezhet."

Az atomerőmüvi, tágabban technológiai előírások és szabályok kapcsán az elsődleges elvárás, hogy a célszemélyek (atomerőmüvi operátorok, tágabban szabályalkalmazók) az elöírást előírásjellegüknél fogva, pusztán fegyelmezettségi alapon tartsák be. Amennyiben azonban a szabálykövetés kérdése ilyen egyszerűen elintézhető lenne, nem lenne jelentősége a hiányos elöírás hibának, jelesül, hogy a vonatkozó előírások kizárólag az ORM teljesítményszabályozási funkcióját állították előtérbe, és mellőzték vészhelyzeti védelmi szerepét. Az engedelmesség alapú szabálykövetésből fakadó elvárás alapján végül is mindegy lenne, hogy az operátorok milyen alapon tartják be az előirást, ha betartják. Az elöírás lehetne akár tévesen vagy hiányosan megalapozott, ám ha a fennálló helyzetet helyesen kezeli, akkor az engedelmesség alapú betartása ugyanarra a kívánatos eredményre vezet, mint a helyzet szempontjából megfelelő elöírása.

Így a reaktivitási tartalékra vonatkozó előírásokkal kapcsolatban megfogalmazott INSAG-7 észrevételek első értelme az, hogy a szabályok megszegésével kapcsolatban más jellegü tényezők is szerepet játszanak, mint az ellentmondásosság. Az észrevételek második értelme, hogy a szabálybetartásra vonatkozó elvárás feltételez olyan további tényezőket, amelyeken a betartási szándék múlik. E további tényezők leírására, megragadására azonban az engedelmesség alapú szabálykövetés nem alkalmas, a tényezők kívül esnek a leíró fogalom hatályán.

Végeredményben az INSAG-jelentés, alapvetően hallgatólagosan, de kilép abból a keretböl, hogy a szabálybetartási szándékot pusztán engedelmességi kérdésként kezelje. Ezt úgy kell értelmeznünk, hogy a NAÜ nem az engedelmesség alapú előiráskövetés elvárását vagy elsődleges jellegét adja fel, hanem beismeri, szintén hallgatólagosan, hogy az engedelmességre alapozni szükséges, de nem elégséges. Ennek azonban van előremutató tanulsága: az elöírások betartási szándékát érdemben befolyásoló tényezők elismerése vizsgálhatóvá, feltárhatóvá, megragadhatóvá teszi őket. Így további kutatási kérdések tárgyává tehető, hogy a szabályvezérelt viselkedés más esetei, mint az igazodás alapú vagy a kiterjesztés alapú szabálykövetés segítenek-e a betartási szándék erősítésében, gyengítésében, végső esetben pedig kioltásában. További nyitott kutatási kérdésként adódik, hogy a szabályvezérelt viselkedés e két utóbbi esete hogyan segíthet az előírások megfogalmazásában és a szabálykövetési környezet kialakításában.

\section{Irodalomjegyzék}

[1] sz.n. (1992): „The Chernobyl Accident: Updating of INSAG-1. INSAG-7: A Report by the International Nuclear Safety Advisory Group", Safety Series No. 75-Insag-7. International Atomic Energy Agency: Vienna.

https://www-pub.iaea.org/MTCD/publications/PDF/Pub913e web.pdf

[2] Szathmáry, Z., Aszódi A. (2005): Csernobil. Tények, okok, hiedelmek. Budapest: Typotex Kiadó: Budapest.

[3] Plokhy, S. (2018): The History of a Nuclear Catastrophe. New York: Basic Books.

[4] Malko, Mikhail V. (2002) „The Chernobyl Reactor: Design Features and Reasons for Accident”, in: Imanaka, T. (2002): Recent Research Activities about the Chernobyl NPP Accident in Belarus, Ukraine and Russia. Research Reactor Institute: Kyoto University. pp. 11-27., http://large.stanford.edu/courses/2014/ph241/alnoaimi2/docs/kr79.pdf

[5] Törneke, N., Luciano, C., Valdivia-Salas, S. (2008): „Rule-Governed Behavior and Psychological Problems”, International Journal of Psychology and Psychological Therapy. vol. 8, no. 2. pp. 141-156. https://www.ijpsy.com/volumen8/num2/191/rule-governed-behavior-and-psychological-EN.pdf

[6] Kissi, A., Hughes, S., Mertens, G., Barnes-Holmes, D., Houwer, J.D., Crombez, G. (2017): „A Systematic Review of Pliance, Tracking, and Augmenting”, Behavior Modification 41(5), pp. 683-707. DOI: 10.1177/0145445517693811 doi.org/10.1177/0145445517693811 